\title{
Interaction between extracellular lipase LipA and the polysaccharide alginate of Pseudomonas aeruginosa
}

Petra Tielen ${ }^{1,4^{*}}$, Hubert Kuhn ${ }^{2}$, Frank Rosenau ${ }^{3,5}$, Karl-Erich Jaeger $^{3}$, Hans-Curt Flemming $^{1}$ and Jost Wingender ${ }^{1}$

\begin{abstract}
Background: As an opportunistic human pathogen Pseudomonas aeruginosa is able to cause acute and chronic infections. The biofilm mode of life significantly contributes to the growth and persistence of $P$. aeruginosa during an infection process and mediates the pathogenicity of the bacterium. Within a biofilm mucoid strains of $P$. aeruginosa simultaneously produce and secrete several hydrolytic enzymes and the extracellular polysaccharide alginate. The focus of the current study was the interaction between extracellular lipase LipA and alginate, which may be physiologically relevant in biofilms of mucoid $P$. aeruginosa.
\end{abstract}

Results: Fluorescence microscopy of mucoid $P$. aeruginosa biofilms were performed using fluorogenic lipase substrates. It showed a localization of the extracellular enzyme near the cells. A microtiter plate-based binding assay revealed that the polyanion alginate is able to bind LipA. A molecular modeling approach showed that this binding is structurally based on electrostatic interactions between negatively charged residues of alginate and positively charged amino acids of the protein localized opposite of the catalytic centre. Moreover, we showed that the presence of alginate protected the lipase activity by protection from heat inactivation and from degradation by the endogenous, extracellular protease elastase LasB. This effect was influenced by the chemical properties of the alginate molecules and was enhanced by the presence of O-acetyl groups in the alginate chain.

Conclusion: We demonstrate that the extracellular lipase LipA from P. aeruginosa interacts with the polysaccharide alginate in the self-produced extracellular biofilm matrix of $P$. aeruginosa via electrostatic interactions suggesting a role of this interaction for enzyme immobilization and accumulation within biofilms. This represents a physiological advantage for the cells. Especially in the biofilm lifestyle, the enzyme is retained near the cell surface, with the catalytic centre exposed towards the substrate and is protected from denaturation and proteolytic degradation.

Keywords: Biofilm, Lipase, Polysaccharide, Interaction, Enzyme stability, Molecular modeling

\section{Background}

Pseudomonas aeruginosa is a Gram-negative bacterium which is ubiquitous in water and soil. It is able to produce and secrete several hydrolases which are important for nutrition of the bacterium, for biofilm structure [1] and, moreover, as virulence factors [2]. As an opportunistic human pathogen, $P$. aeruginosa can cause severe acute and chronic infections, especially in immuno-compromized

\footnotetext{
*Correspondence: p.tielen@tu-bs.de

'Department of Aquatic Microbiology, University of Duisburg-Essen, Faculty of Chemistry, Biofilm Centre, Universitätsstrasse 5, D-45141, Essen, Germany ${ }^{4}$ Current adress: Institute for Microbiology, Technische Universität Braunschweig, Spielmannstrasse 7, D-38106, Braunschweig, Germany Full list of author information is available at the end of the article
}

patients. In addition to infections of the urinary tract, wounds, middle ear and eyes, $P$. aeruginosa is well known as the causative agent of chronic lung infections of cystic fibrosis (CF) patients [3]. Most of these infections are biofilm-associated $[4,5]$. Biofilms represent a bacterial state of life in which the cells are attached to biotic or abiotic surfaces or to each other. Thereby, they are embedded in a matrix of self-produced extracellular polymeric substances (EPS). Different amounts of polysaccharides, lipids, nucleic acids and proteins can be detected in the EPS matrix of biofilms formed by P. aeruginosa. Part of the proteins show enzyme activities in vitro and in vivo. The expression of several exoenzyme encoding genes was detected in the sputum of infected CF-patients by transcriptome analysis

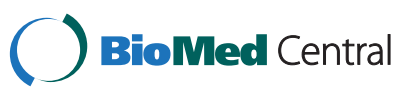


[6] and the presence of significant levels of extracellular enzyme specific antibodies in sera of infected CF patients is an indirect evidence for the production of extracellular enzymes during infection processes $[7,8]$. Therefore, the biofilm matrix of $P$. aeruginosa was described as a reservoir of enzymes [9].

The main extracellular enzymes produced by $P$. aeruginosa are type I and II-secreted hydrolases, including alkaline protease [10], elastase A (LasA) and B (LasB) [11], phospholipase $C$ [12] and lipases [13,14]. These enzymes alone or synergistically with others are causing cell death, severe tissue damage and necrosis in the human host $[2,15,16]$. The simultaneous production of these exoenzymes and polysaccharides were described for $P$. aeruginosa $[17,18]$. During persistent CF-lung infections the conversion to a mucoid, i.e. an alginate overproducing phenotype is commonly observed [19]. Alginate is a highmolecular weight extracellular copolymer consisting the uronic acid monomers $\beta$-D-mannuronate and its C-5 epimer $\alpha$-L-guluronate, which are linked by 1,4 -glycosidic bonds $[20,21]$. These components are arranged in homopolymeric blocks of poly- $\beta$-D-mannuronate and heteropolymeric sequences with random distribution of mannuronate and guluronate residues [22]. In contrast to the alginate produced by brown algae the alginate from $P$. aeruginosa contains $\mathrm{O}$-acetyl groups on the $\mathrm{C} 2$ - and/or C3-position of the $\beta$-D-mannuronate residues. This acetylation significantly influences the physico-chemical properties of the polymer, such as the viscosity [23,24], the ability to bind divalent cations [23,25] and the water-binding capacity [26]. All of these features are important for the structure and the mechanical stability of the biofilm [24,27,28]. The extracellular alginate forms a highly hydrated matrix in which the bacteria cells are embedded. It can protect the cells from dehydration, the activity of antimicrobial substances as antibiotics [29] and disinfectants [30] and, moreover, protects the cells from the immune system during the infection process [31,32]. Several reports described the binding of extracellular enzymes such as lipases to this polysaccharide [33-35], but the type and molecular mechanism of this interaction are still unclear.

Lipases (EC 3.1.1.3) are physiologically and biotechnologically relevant enzymes. In addition to their natural function (hydrolysis of triglycerides), lipases are also able to recognize various substrates and catalyze regio- and enantioselective hydrolysis of many esters. The main extracellular lipase of $P$. aeruginosa is the $29 \mathrm{kDa}$ lipase LipA [13], which belongs to the I.1 family of lipases [36]. $\mathrm{X}$-ray studies showed that lipases of this family exhibit an $\alpha$-helical lid structure, which closes the active centre of the enzyme [37]. The open, active conformation occurs only in contact with the substrate. This complex mechanism is called interfacial activation and can be mediated by a large range of hydrophobic substances, including lipopolysaccharides (LPS) [13]. However, LipA exhibits a lid structure, it does not show an interfacial activation, because interaction with hydrophobic outer membrane components let to a permanent open conformation $[13,38]$. Lipase LipA is transported across the cell envelope by the type II secretion system, the main two-step ATPdependent process of Gram-negative bacteria [39]. It has been reported that mucoid $P$. aeruginosa strains showed up to 9-fold higher lipase activity than their spontaneous non-mucoid counterparts [40]. The exogenous supplementation of purified bacterial alginate from P. aeruginosa and Azotobacter vinelandii and also algal alginate to the culture media of non-mucoid $P$. aeruginosa strains increases the release of extracellular lipase from the bacterial cells [33]. It has been hypothesized that this enhanced release of lipase was due to a non-covalent association between lipases and alginate [33]. The co-secretion of LipA and alginate from $P$. aeruginosa cells may reinforce the synthesis of lipases. Thereby, the removal of the enzyme from the direct cell surface acts as a signal for the bacterial cell [41]. The interaction between lipase and alginate was further used for lipase purification strategies by ethanolic co-precipitation of the two molecules [34,35]. Beside the biotechnological relevance of this finding, the physiological function of the interaction between extracellular lipase and the polysaccharide alginate for the bacterium remains unclear.

Here, we demonstrate that lipase LipA from $P$. aeruginosa binds to the extracellular polysaccharide alginate by electrostatic interactions. This interaction localizes the enzyme near the cell surface and enhances the stability of the enzyme against heat and degradation by endogenous proteases.

\section{Results and discussion}

\section{Expression of lipase in mucoid Pseudomonas aeruginosa} biofilms

The activity of extracellular lipolytic enzymes in P. aeruginosa was investigated in biofilms grown on the surface of membrane filters placed on agar plates (PIA) at $36^{\circ} \mathrm{C}$ for $24 \mathrm{~h}$ (Table 1). Biofilms were grown from mucoid environmental strain P. aeruginosa SG81, strain SG81 $\Delta$ lipA defective for LipA production, strain SG81 $\operatorname{lipA}$ ::lipA with complementation of the lipA gene deletion in trans by plasmid pBBL7, LipA-overproducing strain SG81lipA + and vector control strain SG81MCS. The membrane filter biofilm model mirrored biofilms in environmental habitats as found in soil or on leaves and also biofilms involved in infections as for example lung infections of cystic fibrosis patients [42-44].

The biofilms of the five strains revealed comparable cell densities between 1.2 and $1.5 \times 10^{9}$ cells $/ \mathrm{cm}^{2}$ (Table 1 ). Extracellular lipase activity was determined in cell-free supernatants of biofilm suspensions by a photometric 
Table 1 Cell density, unronic acid (alginate) content and extracellular lipase activity of agar-grown $P$. aeruginosa biofilms

\begin{tabular}{|c|c|c|c|}
\hline Strain & $\begin{array}{c}\text { Bacterial density } \times \\
10^{9}\left(\text { cells } / \mathrm{cm}^{2}\right)\end{array}$ & $\begin{array}{l}\text { Uronic acids } \\
\left(\mu \mathrm{g} / \mathrm{cm}^{2}\right)\end{array}$ & $\begin{array}{c}\text { Lipase activity } \\
\left(\mathrm{nmol} / \mathrm{min} \times \mathrm{cm}^{2}\right)\end{array}$ \\
\hline SG81 & $1.4 \pm 0.3$ & $0.22 \pm 0.01$ & $0.12 \pm 0.01$ \\
\hline SG81MCS & $1.3 \pm 0.2$ & $0.23 \pm 0.01$ & $0.14 \pm 0.01$ \\
\hline SG81 $\Delta / i p A$ & $1.2 \pm 0.1$ & $0.22 \pm 0.01$ & $0.0 \pm 0.0$ \\
\hline SG81_lipA::/ipA & $1.5 \pm 0.6$ & $0.23 \pm 0.03$ & $6.50 \pm 0.1$ \\
\hline SG81/ipA+ & $1.4 \pm 0.2$ & $0.23 \pm 0.01$ & $63.02 \pm 5.2$ \\
\hline
\end{tabular}

The mucoid parent strain $P$. aeruginosa SG81 and its derivative strains (vector control SG81MCS, lipA mutant SG81 $\Delta$ lipA, complementation strain SG81 lipA: $\operatorname{lip} A$ and lipA overexpression strain $\mathrm{SG} 81$ lipA+) were tested. The results are expressed as mean values of four independent experiments.

assay, using para-nitrophenylpalmitate (pNPP) as a substrate. The parent strain and the vector control strain showed similar levels of extracellular lipase activity, whereas no extracellular lipase activity was detected in biofilms of the lipA mutant. Complementation of lipA in strain SG81 $\triangle$ lipA::lipA restored lipase activity, and the lipA overexpression strain displayed significantly enhanced lipase activity that was 525-fold higher compared with the parent strain SG81 (Table 1). Uronic acids (alginate) were detected in all biofilms at nearly the same levels, indicating that alginate production was not influenced by the differential expression of lipase activities.

\section{Localization of lipase activity in Pseudomonas aeruginosa biofilms}

In order to visualize lipase activity in situ, fluorescence micrographs of biofilms of the mucoid $P$. aeruginosa strain SG81 and its derivates were made using the fluorigenic lipase substrate ELF'-97-palmitate (Figure 1). An emulsion of the water insoluble ELF-97-palmitate was prepared using sodium desoxycholate and gum arabic for emulsification and stabilisation of the substrate according to the well-established method for lipase activity determination with pNPP as a substrate [45]. Biofilms were grown on agar medium (PIA) supplemented with $0.1 \mathrm{M} \mathrm{CaCl}_{2}$ for stabilization of the biofilm matrix, since $\mathrm{Ca}^{2+}$ ions enhance the mechanical stability of $P$. aeruginosa biofilms by complexing the polyanion alginate $[25,28,46]$. This facilitates the treatment of the biofilms necessary for activity staining and subsequent observation by confocal laser scanning microscopy (CLSM).

A heterogeneous distribution of lipase activity within the biofilms was observed (Figure 1). Cellular activity in most of the cells indicated by the yellow colour and extracellular red-coloured regions surrounding the cells could be distinguished. Significantly more extracellular lipase activity was detected in the LipA overproducing strain $P$. aeruginosa SG81lipA+, indicating that the

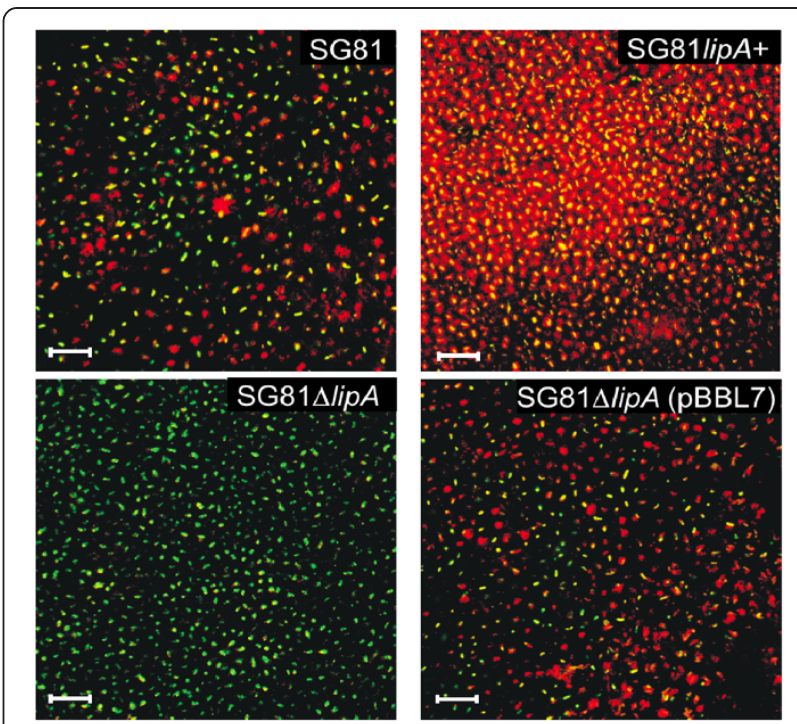

Figure 1 Visualization of lipase activity in biofilms of $P$. aeruginosa. Membrane filter biofilms (PIA $\left.+\mathrm{Ca}^{2+}, 24 \mathrm{~h}, 36^{\circ} \mathrm{C}\right)$ of the parent strain $P$. aeruginosa SG81, the lipA overexpression strain SG81lipA+, the lipA defect mutant SG81 $\triangle$ lipA and their corresponding complementation strain SG81 $\Delta$ lipA::/ipA were stained using the lipase substrate ELF ${ }^{\circledR}$-97-palmitate. Shown are CLSM micrographs (optical section in the vertical middle of the biofilms) at a 400-fold magnification. For cell staining SYTO 9 (green) were used. Lipase activity, red; cells, green; overlay, yellow. The bars indicate $20 \mu \mathrm{m}$

visualized extracellular lipase activity was mainly based on the activity of LipA. No extracellular but weak cellassociated activity was observed in the lipase mutant $P$. aeruginosa SG81 $\operatorname{lipA}$. This can be explained by the activity of other lipolytic enzymes such as the outermembrane bound esterase EstA, which is able to degrade palmitate [14,47]. The second extracellular lipase LipC of $P$. aeruginosa is unable to degrade palmitate ester substrates (personal communication). Furthermore, a deletion within the foldase gene lipH may also affect folding and activity of LipC [39]. The defect of extracellular lipolytic activity could be complemented by the expression of lipA in trans from the plasmid pBBL7. Accordingly, the complementation strain $P$. aeruginosa SG81 $\triangle$ lipA::lipA revealed a level of lipase activity staining of the biofilms similar to the parent strain $P$. aeruginosa SG81. The biochemical detection of lipase activity in cell-free material from biofilms and the in situ visualization of lipase activity in the intercellular space of biofilms using palmitate-based enzyme substrates indicate that extracellular lipase is expressed in biofilms of mucoid $P$. aeruginosa, so that the biofilm matrix represents a reservoir of lipase molecules. By the use of strains that differ in their ability of producing LipA indicated that the major activity of extracellular lipase is due to the presence of lipase LipA. 


\section{Binding of lipase LipA to alginate}

Previous in vitro studies have demonstrated the stimulation of lipase release from non-mucoid wild-type $P$. aeruginosa by the addition of purified algal and bacterial alginate to cell suspensions. Moreover, the interaction of lipases and algal alginate with a concomitant stabilization of the enzyme against ethanol-induced denaturation was shown in vitro. On the basis of these observations we hypothesized that extracellular lipase in mucoid $P$. aeruginosa biofilms might be bound to the alginate in the EPS matrix. Therefore, in vitro binding studies in a microtiter plate assay were conducted using purified LipA from $P$. aeruginosa and bacterial alginate isolated from mucoid P. aeruginosa SG81 biofilms. For comparison, different neutral (dextran, levan) and negatively charged polysaccharides (algal alginate, xanthan) were tested. The immobilization of the polysaccharides on the polystyrene of the microtiter plate was verified by carbohydrate quantification. Binding of polysaccharides to wells of polystyrene microtiter plates in a concentration of $0.01-1.0 \mathrm{mg} / \mathrm{ml}$ was also shown before [48].

After two washing steps with $200 \mu \mathrm{l}$ water each, a significantly increased lipase activity was detected in the wells of the microtiter plate with increasing amounts of bacterial alginate used for coating of the wells (Figure 2). This observation indicated that LipA bound to the immobilized bacterial alginate in a concentrationdependent manner. In the absence of polysaccharides no lipase activity was detected within the microtiter plate after the performed washing steps $\left(\Delta \mathrm{A}_{405} \leq 0.07\right)$ indicating that LipA did not bind to the polystyrene surface (Figure 2). Without washing the lipase activity was $\Delta \mathrm{A}_{405}=0.8+/-0.1$ independent of the presence or absence of polysaccharides. This result indicated that no interfacial activation of the lipase occurs by the presence of polysaccharides. It was reported that the enzyme exhibits a permanent open conformation [13]. Interestingly, no binding of LipA to the neutral polysaccharide dextran (poly- $\alpha$-D-glucose) and only minor binding of LipA to levan (poly- $\beta$-D-fructose) was detected. These results suggested an influence of negative charges of the polysaccharides on the binding of lipase. A binding of LipA to xanthan was observed only at high concentrations of the polysaccharide. Xanthan is a heteropolymer of glucose, mannose and glucuronic acid, which is substituted with acetate and pyruvate residues. Therefore, this polysaccharide displays neutral as well as anionic properties and thus the charge density of xanthan was reduced in relation to alginate. Consequently, higher concentrations of this polysaccharide seemed to be necessary to bind measurable amounts of lipase molecules. In comparison to bacterial alginate, algal alginate showed a minor binding capaticity. However, binding of lipase to algal alginate was reported previously [34]. In

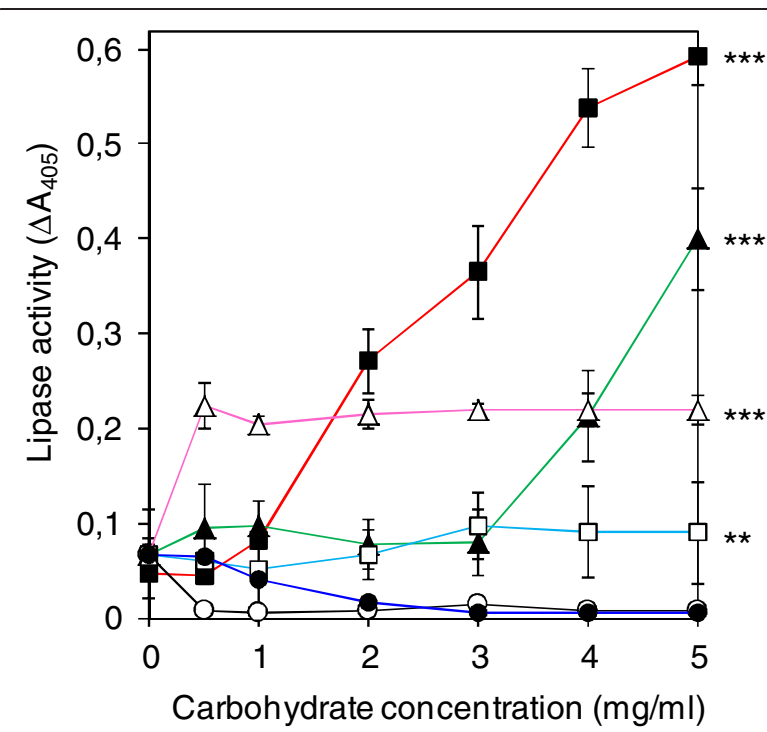

Figure 2 Binding of purified lipase LipA from $P$. aeruginosa to polysaccharides. Purified lipase LipA ( $36 \mathrm{ng} / \mathrm{ml}$ ) from $P$. aeruginosa was incubated at $30^{\circ} \mathrm{C}$ in microtiter plates in the absence (-o-) and in the presence of immobilized polysaccharide films of (- - - -) bacterial alginate from $P$. aeruginosa SG81 shown in red, $(-\boldsymbol{\Lambda}-)$ xanthan shown in green, $\left(-\Delta^{-}\right)$algal alginate shown in pink, $\left(-\square^{-}\right)$ levan shown in bright blue and (- -) dextran shown in dark blue. Represented are carbohydrate concentrations used for coating of the microtiter plate wells. The bound lipase was detected by activity measurements using pNPP as substrate. Results are shown as mean of five independent experiments +/- standard deviations.

Significance of differences in lipase binding between coated and uncoated wells was calculated by ANOVA for the highest tested polysaccharide concentration. ${ }^{* *} p<0.001 ;{ }^{* *} p<0.01$

contrast to bacterial alginate of $P$. aeruginosa, the algal alginate lacks $\mathrm{O}$-acetyl groups and comprises a different monomer sequence which is characterized by the presence of guluronic acid rich regions (G-blocks) [22,49]. Since other studies did not reveal an influence of the Oacetyl groups on the binding of lipases [33] the here observed effect might be based on the different monomer structure of algal and bacterial alginates. It was shown that within the G-blocks of algal alginates specific intra- and intermolecular structures were formed (egg box). Within the egg boxes negative charges of the alginate molecules are directed to each other and are complexed via divalent cations. Thereby, the negative charges were shielded [50].

In summary, the experiments suggest that the binding of lipases to alginate depends on the negative charged monomers of the polysaccharide indicating ionic interactions between the molecules.

\section{Heat stabilization of lipases by polysaccharides}

To investigate the biological impact of the interaction between lipase and bacterial alginate, heat inactivation experiments were performed. Incubation of purified lipase for $20 \mathrm{~min}$ at different temperatures in the presence 
and absence of polysaccharides showed an obvious influence of alginate on the stability of the lipase activity (Table 2). Without heat treatment $\left(37^{\circ} \mathrm{C}\right)$ lipase activity stayed constant over $20 \mathrm{~min}$ in the presence and absence of polysaccharides at $\Delta \mathrm{A}_{401}=0.66+/-0.15$ corresponding to an activity of $2.3+/-0.5 \mathrm{nmol} / \mathrm{min} \times \mu \mathrm{g}$ protein. Furthermore, at temperatures up to $50^{\circ} \mathrm{C}$ the lipase seemed to be generally stable. The addition of polysaccharides only had a minor effect. At higher temperatures $\left(>80^{\circ} \mathrm{C}\right.$ ) the protective effect of polysaccharides was lost. However, at approximately $70^{\circ} \mathrm{C}$ a significantly increased temperature tolerance of the lipase was observed in the presence of bacterial alginate. Interestingly, a $2-3^{\circ} \mathrm{C}$ higher heat tolerance was obtained by the addition of alginates without $\mathrm{O}$-acetyl groups compared to their $\mathrm{O}$ acetylated equivalent (Figure 3). This effect was slightly stronger for the chemically deacetylated alginate from $P$. aeruginosa SG81 than for the alginate of the Oacetylation mutant $P$. aeruginosa FRD1153. This might be explained by the fact that the alginate of $P$. aeruginosa FRD1153 still contained a residual of $9 \%(\mathrm{w} / \mathrm{w})$ of O-acetyl groups, whereas the chemically deacetylated alginate of $P$. aeruginosa SG81 was free of O-acetyl groups [24]. No protection of lipase activity was obtained by the addition of dextran and minor in the presence of algal alginates. Xanthan showed comparable protection ability as the bacterial alginate of $P$. aeruginosa SG81. These results were in accordance with the finding that the lipase did not or only slightly bind to these polysaccharides at a concentration of $1 \mathrm{mg} / \mathrm{ml}$ in the microtiter plate assay (Figure 2).

In summary, the protection effect of alginate occurred mainly at temperatures between $50^{\circ} \mathrm{C}$ and $80^{\circ} \mathrm{C}$. The

Table 2 Inactivation temperatures of lipase LipA calculated by extrapolation of the linear gradient of the heat inactivation curves

\begin{tabular}{lccc}
\hline Sample & $\begin{array}{c}\mathbf{T}_{\mathbf{1 0 0}} \\
\left({ }^{\circ} \mathbf{C}\right)\end{array}$ & $\begin{array}{c}\mathbf{T}_{\mathbf{5 0}} \\
\left({ }^{\circ} \mathbf{C}\right)\end{array}$ & $\begin{array}{c}\mathbf{T}_{\mathbf{0}} \\
\left({ }^{\circ} \mathbf{C}\right)\end{array}$ \\
\hline Tris-HCl buffer (control) & $45.0+/-2.5$ & $63.8+/-1.1$ & $82.7+/-2.9$ \\
Alginate FRD1 & $45.1+/-3.5$ & $72.2+/-2.6$ & $101.7+/-2.8$ \\
Alginate FRD1153 & $47.3+/-2.2$ & $76.7+/-1.2$ & $106.2+/-3.2$ \\
Alginate SG81 & $47.9+/-2.5$ & $70.3+/-3.3$ & $91.0+/-3.0$ \\
Alginate SG81, deacetylated & $49.2+/-3.5$ & $78.5+/-1.9$ & $109.0+/-3.0$ \\
Algal alginate & $54.0+/-4.7$ & $68.1+/-2.7$ & $87.2+/-3.4$ \\
Dextran & $46.1+/-3.2$ & $66.1+/-3.2$ & $86.2+/-3.4$ \\
Xanthan & $47.8+/-3.9$ & $74.1+/-1.5$ & $95.4+/-2.7$ \\
\hline
\end{tabular}

The lipase activity was detected after 20 min incubation at different temperatures in the presence $(1 \mathrm{mg} / \mathrm{ml})$ and absence of polysaccharides. Three independent experiments were performed in duplicates. Shown are $T_{0}$ representing the temperature of complete inactivation of lipase activity, $T_{50}$ which represents the temperature at which the lipase activity was reduced by half and $T_{100}$ designated the maximum temperature where lipase activity remained unaffected within 20 min of incubation.

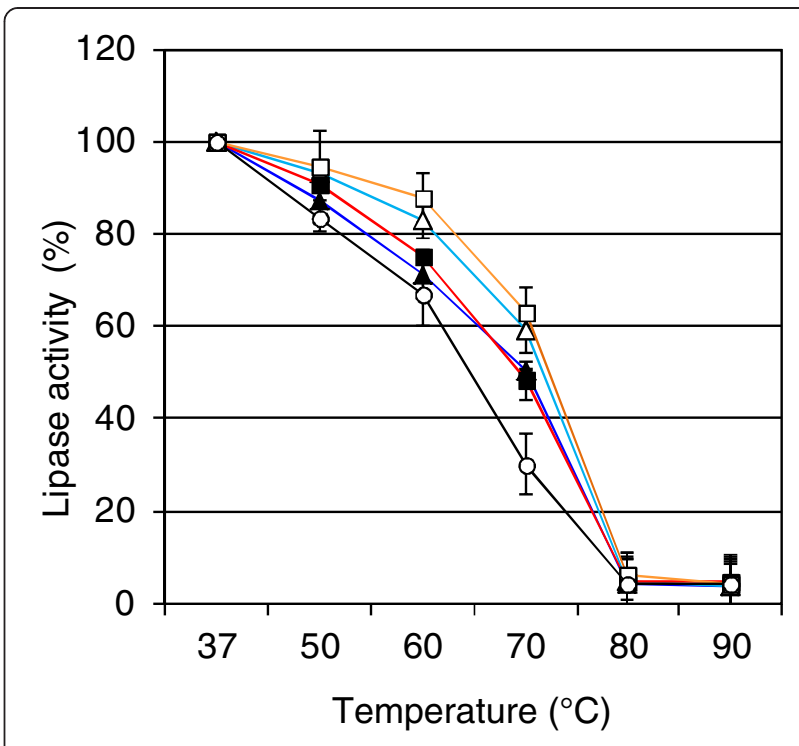

Figure 3 Temperature-dependent heat inactivation of lipase LipA. Purified lipase LipA $(18 \mathrm{ng} / \mathrm{ml})$ from P. aeruginosa was incubated for $20 \mathrm{~min}$ in the absence (-0-) and in the presence of $1 \mathrm{mg} / \mathrm{ml}(-\mathbf{-})$ bacterial alginate from $P$. aeruginosa SG81 shown in red, (---) deacetylated bacterial alginate from $P$. aeruginosa SG81 shown in orange, (-) bacterial alginate from $P$. aeruginosa FRD1 shown in dark blue, $\left.(-\rangle_{-}\right)$bacterial alginate from $P$. aeruginosa FRD1153 shown in bright blue. Results are shown as mean of three independent experiments with standard deviations.

inactivation of lipase activity at $70^{\circ} \mathrm{C}$ was investigated in more detail over an increased incubation time (Figure 4). In general, similar results were obtained even over a prolonged incubation time of $60 \mathrm{~min}$. Bacterial alginates revealed a protection effect on LipA, which was found enhanced in case of deactetylated alginates. As seen above (Table 2), algal alginate did only slightly protect LipA from heat inactivation. Furthermore, dextran showed a protective effect on LipA activity at longer incubation times similar to that of algal alginate. This result was unexpected, since in contrast to algal alginate LipA did not bind to dextran in the microtiter plate assay. Interestingly, also over a prolonged time of incubation the addition of xanthan led to similar lipase activities as detected for bacterial alginate treated lipase. However, at the polysaccharide concentration of $1 \mathrm{mg} / \mathrm{ml}$ no binding of LipA was detectable (Figure 2). Nevertheless, this experiment indicated a comparable protective function of the negative-charged polysaccharides xanthan and bacterial alginate.

The interaction of enzymes with polysaccharides and the influence on the stability of the proteins was described earlier $[35,51,52]$. Heat stabilization effects were also reported for extracellular lipases from $P$. aeruginosa [34]. According to our results, the residual lipase activity after $60 \mathrm{~min}$ at $70^{\circ} \mathrm{C}$ in the presence of algal alginate was $15 \%$ of the initial activity. Also the stabilization of other 


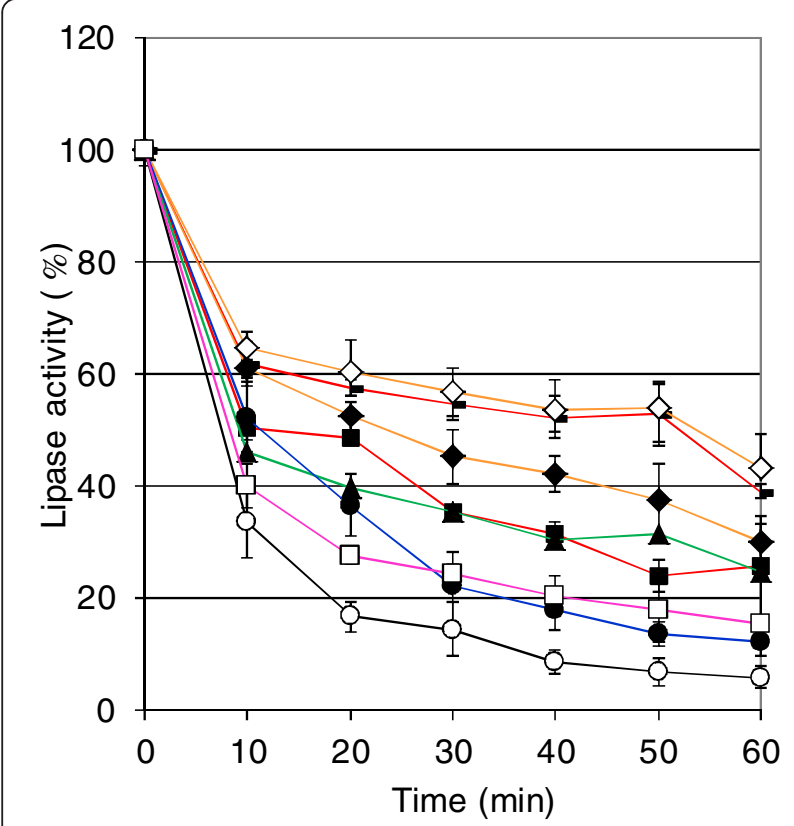

Figure 4 Time-dependent heat inactivation of lipase LipA. Purified lipase LipA $(18 \mathrm{ng} / \mathrm{ml})$ from P. aeruginosa was incubated at $70^{\circ} \mathrm{C}$ in the absence (-o-) and in the presence of $1 \mathrm{mg} / \mathrm{ml}(-\mathbf{-}-)$ bacterial alginate from $P$. aeruginosa SG81 shown in red, (---) deacetylated bacterial alginate from $P$. aeruginosa SG81 shown in red, (- - bacterial alginate from $P$. aeruginosa FRD1 shown in orange, $(-\diamond-)$ bacterial alginate from $P$. aeruginosa FRD1153 shown in orange, (-口-) algal alginate shown in pink, (- $\mathbf{\Delta}-)$ xanthan shown in green and (-•-) dextran shown in blue. Results are shown as mean of five independent experiments with standard deviations.

bacterial extracellular enzymes by non-covalent associations with exopolysaccharides from the same bacterial species has been described before [53,54]. This thermostabilizing effect might be relevant for survival of biofilm grown $P$. aeruginosa cells in environmental habitats under conditions of elevated temperatures as for example sunshined soil or heated water bodies.

\section{Protection of lipase from proteolytic degradation}

Another biological function of such interactions may be the stabilization of the enzyme and the protection from proteolytic degradation. To address this question, the stability of LipA in the presence of the endogenous elastase LasB purified from $P$. aeruginosa was tested (Figure 5).

A significantly decreased lipase activity was detected after $24 \mathrm{~h}$ incubation with LasB in the absence of alginate $\left(p=7.9 \times 10^{-6}\right)$. In contrast, no activity was lost in the presence of alginate. Moreover, the experiment again clearly showed that the addition of alginate did not stimulate the lipase activity, since the activity was similar in presence and absence of alginate. A stimulation of lipase activity would be a hint on conformational changes of the lipase protein. However, this seemed not to be happened.

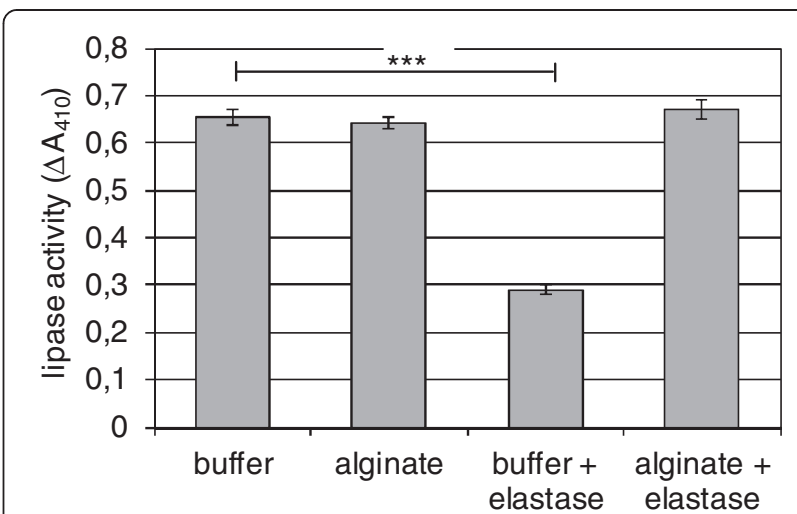

Figure 5 Proteolytic degradation of lipase LipA through endogenous LasB. Purified lipase LipA $(18 \mathrm{ng} / \mathrm{ml})$ from $P$. aeruginosa was incubated for $24 \mathrm{~h}$ at $37^{\circ} \mathrm{C}$ with $0.5 \mathrm{U}$ purified LasB from $P$. aeruginosa (EMD4 Bioscience) in the absence and in the presence of bacterial alginate from $P$. aeruginosa SG81. A representative experiment of two independent experiments with standard deviations of the duplicates is shown. ${ }^{* *} p<0.001$.

Lipase activity was found similar in the presence and in the absence of alginate without proteolytic treatment. Furthermore, no interfacial activation of the lipase was observed. This was expected as discussed above. However, elastase activity measured at the end of the experiment revealed constant over time. These results led to the suggestions that i) LasB is able to degrade the lipase LipA and ii) alginate protects the lipase molecule from degradation, possibly by covering of cleavage sites.

Elastase LasB has been described as one of the major extracellular proteases of $P$. aeruginosa [2]. The influence of LasB on the biofilm structure of mucoid P. aeruginosa was shown recently [1]. It was hypothesized that the proteolytic degradation of extracellular proteins mediated by LasB changes the physico-chemical properties of the EPS of $P$. aeruginosa and thereby, influences the structure of the biofilm [1]. Accordingly, a post-translational degradation of extracellular proteins during $P$. aeruginosa biofilm maturation was shown by proteome analysis [55]. Thereby, LasB has been identified as one of the enzymes involved [56]. Post-translational proteolytic processing cascades of extracellular proteins have also been found in other organisms $[57,58]$.

\section{Modeling of interaction between lipase and polysaccharide alginate}

Molecular modeling of inter- and intramolecular interactions between the extracellular lipase LipA and the exopolysaccharide alginate from $P$. aeruginosa was performed by molecular mechanics force field approach using a minimized energy simulation strategy (Figure 6). The crystal structure of the extracellular lipase LipA from $P$. aeruginosa [37] and a section of an alginate molecule were used. The modeling was carried out in presence and 


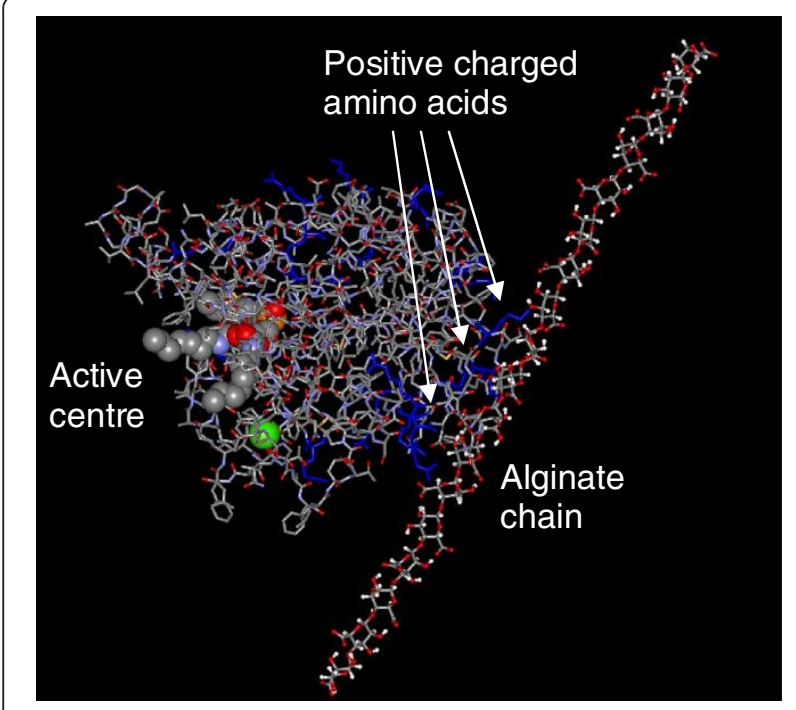

Figure 6 Model of interaction between lipase A and alginate from $\boldsymbol{P}$. aeruginosa. Left: Lipase protein in presence of an inhibitor molecule in the active centre of the enzyme [37]. Furthermore, the co-factor molecule $\mathrm{Ca}^{2+}$ is indicated in green. Site chains of positively charged amino acids are shown in blue. Right: Section of an alginate molecule composed of negatively charged uronic acids in ball and stick representation. For better visibility the water in the reaction room is not shown (Redrawn from [9]).

absence of water showing similar results. The calculations revealed that the interaction between lipase and alginate is mainly based on electrostatic interactions between negatively charged carboxyl groups of the polysaccharide and the positively charged amino acids of the protein as arginine, lysine and histidine (Figure 6, shown in blue). Mainly arginine, which is positively charged by the guanidinium group formed dominant interactions with the alginate chain. In accordance, the interaction remained stable even in the presence of water, whereas the histidine- and lysine-alginate interactions were slightly weakened. The binding to alginate let to a slight change in conformation of the whole protein, including the catalytic centre. However, it did not influence the activity of the enzyme (see above).

The interaction between alginate and lipases was hypothesized previously to be predominantly polar and nonspecific, since addition of $\mathrm{NaCl}$ impaired co-precipitation, whereas Triton X-100 did not [34,41]. In a number of other studies the formation of complexes of alginate with various proteins such as trypsin, $\alpha$-chymotrypsin, albumins, human leukocyte elastase and myoglobin has been demonstrated $[41,59,60]$ underlining the non-specific binding of alginate to proteins.

Interestingly, the positively charged amino acids are localized on the surface of the protein mainly opposite of the active centre. This resulted in an immobilisation of the protein, while the reactive part of the biocatalyst remains unaffected and is directed to the surrounding environment and the substrate-containing reaction room.

\section{Conclusion}

We demonstrate a binding of extracellular lipase LipA to the endogenous exopolysaccharide alginate from $P$. aeruginosa based on electrostatic interactions. This interaction has important biological advantages for the bacterium in biofilms. First, it prevents extracellular lipases from being rapidly diluted into the surrounding environment - the lipase accumulates and is immobilized near the cells within the alginate matrix, which facilitates the uptake of fatty acids released by the action of lipases. Moreover, the interaction between alginate and the backbone of the protein helps to direct the catalytic site of the enzyme to its substrate and therefore, can enhance the activity level.

A stabilization of the conformation of the enzyme by the interaction with the polysaccharide can be proposed. An evidence for this is the protection against proteolytic degradation and the enhanced heat tolerance of the enzyme. This gives an essential advantage for survival of $P$. aeruginosa under adverse environmental conditions.

\section{Methods}

\section{Bacterial strains and cultivation}

Bacterial strains and plasmids are listed in Table 3. The mucoid environmental strain $P$. aeruginosa strain SG81, the clinical strain FRD1 and its derivate FRD1153, which is defective in O-acetylation of the alginate [24,61,62] were used for the isolation of bacterial alginates. For production and isolation of the extracellular lipase LipA, lipA together with lipH encoding the corresponding chaperone LipH was homologous overproduced in $P$. aeruginosa PABST7.1/pUCPL6A [63]. For lipase activity visualization in biofilms the lipA defect mutant $P$. aeruginosa SG81 $\triangle$ lipA, the corresponding complementation strain $P$. aeruginosa SG81 $\triangle$ lipA::lipA and the lipA overexpression strain $P$. aeruginosa SG81lipA + carrying plasmid pBBL7 were used. This vector based on pBBR1MCS [64] and carries the genes lipA and lipH from $P$. aeruginosa PAO1 [1]. For construction of a $\Delta$ lipA-mutant from SG81 a Gm ${ }^{\mathrm{r}}$ cassette was cloned into the suicide vector pME $\Delta \mathrm{AH} 11$ [63] containing a $2.06 \mathrm{kbp}$ $K p n I / X b a I-f r a g m e n t$ with $\Delta(2 / 3$ lipA $1 / 5$ lipH $)$. The resulting vector $\mathrm{pME} \Delta \mathrm{AH}: \Omega-\mathrm{Gm}^{\mathrm{r}}$ was used for homologous recombination. All plasmids were transferred into $P$. aeruginosa SG81 via conjungation using Escherichia coli $\mathrm{S}-17$.

Biofilm cultures were grown for $24 \mathrm{~h}$ at $36^{\circ} \mathrm{C}$ on Pseudomonas Isolation Agar (PIA; Difco) in the form of confluent mucoid lawns. Cell numbers of biofilms, which were scraped from the agar surface and suspended in $0.14 \mathrm{M}$ 
Table 3 Bacterial strains and plasmids used in this study

\begin{tabular}{|c|c|c|}
\hline Strain/plasmids & Relevant genotype/ phenotype & Reference \\
\hline E. coli S17-1 & 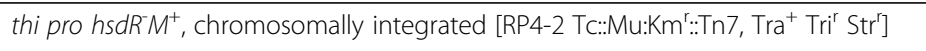 & [65] \\
\hline P. aeruginosa & & [38] \\
\hline PABST7.1/pUCPL6A & Overexpression of lipA and lipH from pUCPL6A & \\
\hline FRD1 & Mucoid $\triangle m u c A 22$ CF-lung isolate & [66] \\
\hline FRD1153 & $\Delta$ algJ5-mutant derived from FRD1, defect in O-acetylation of alginate & {$[61,62]$} \\
\hline SG81 & Mucoid biofilm isolate from technical water system & [67] \\
\hline SG81MCS & Vector control pBBR1MCS & [1] \\
\hline SG81 $\Delta l i p A$ & $\Delta\left(2 / 3\right.$ lipA $1 / 5$ lipH):: $\Omega-G m^{r}$, deletion of lipA and lipH & This study \\
\hline SG81 1 lipA::lipA & Deletion of lipA and lipH complemented in trans from pBBL7 & This study \\
\hline SG81lipA+ & Expression of lipA and lipH in trans from pBBL7 & [1] \\
\hline pBBR1MCS & lacZa Cm mob $\mathrm{P}_{\mathrm{lac}} \mathrm{P}_{\mathrm{T} 7}$ & [64] \\
\hline pBBL7 & $2.8 \mathrm{kbp} \mathrm{Xmnl/Smal} \mathrm{fragment} \mathrm{with} \mathrm{lipA/H} \mathrm{operon} \mathrm{in} \mathrm{pBBR1MCS} \mathrm{under} \mathrm{P}_{\text {lac }}$ control & \\
\hline pME $\triangle \mathrm{AH} 11$ & $2.06 \mathrm{kbp} \mathrm{Kpnl/Xbal-fragment} \mathrm{with} \Delta(2 / 3 \mathrm{lipA} 1 / 5 \mathrm{lipH})$ in pME3087 & [63] \\
\hline pME $\triangle A H:: \Omega-G m^{r}$ & 1.6 kbp Smal-fragment with $\Omega-G m^{r}$ from pBSL142 in pME $\Delta \mathrm{AH} 11$ & This study \\
\hline
\end{tabular}

$\mathrm{NaCl}$, were determined microscopically using a Thoma counting chamber. Cell-free EPS solutions prepared from the biofilm suspensions according to Tielen et al. [1] were used to measure uronic acid (alginate) concentration and lipase activity as described below. For CLSM analysis, biofilms were grown on membrane-filters (polycarbonate, size: $2.5 \mathrm{~cm}$, pore size: $0.4 \mu \mathrm{m}$; Millipore, Billerica, Massachusetts) placed on PIA supplemented with $0.1 \mathrm{M}$ $\mathrm{CaCl}_{2}$ for stabilization of the biofilm matrix as described previously [68].

\section{Visualization of lipase activity in situ}

For visualization of lipase activity in biofilms of $P$. aeruginosa strains, ELF 97 palmitate (Molecular Probes, Invitrogen $\mathrm{GmbH}$, Karlsruhe, Germany) was used as a substrate. This enzyme substrate is cleaved by lipases to the water-insoluble ELF 97 alcohol, which precipitates directly at the site of enzymatic hydrolysis, thus reporting the location of lipase enzyme activity, when visualized by fluorescence microscopy [69]. ELF ${ }^{\circledast} 97$ palmitate obtained as a solid was dissolved at a concentration of $5 \mathrm{mM}$ in isopropanol under weak heating. $1 \mathrm{ml}$ substrate solution was mixed with $9 \mathrm{ml}$ Sørensen phosphate buffer ( $\mathrm{pH}$ 8.0) containing $20.7 \mathrm{mg}$ sodium desoxycholate and $10 \mathrm{mg}$ gum arabic. This substrate emulsion was stored in the dark for maximally $1 \mathrm{~h}$.

24 h-old biofilms on membrane filters cultivated on calcium-amended PIA as described above were covered with $50 \mu \mathrm{l}$ of the substrate emulsion. After incubation for $3 \mathrm{~h}$ at $30^{\circ} \mathrm{C}$ in the dark, lipase activities were detected by fluorescence microscopy using a LSM 510 confocal laser scanning microscope (Zeiss, Jena, Germany) with an excitation wavelength of $351 \mathrm{~nm}$ and emission long pass filter LP $505 \mathrm{~nm}$ or wide pass filter 505-550. In parallel, the biofilm cells were stained with SYTO 9 (Molecular Probes, Invitrogen $\mathrm{GmbH}$, Karlsruhe, Germany) by adding $100 \mu \mathrm{l}$ of SYTO 9 solution $(1.5 \mu \mathrm{l}$ SYTO added to $1 \mathrm{ml} 0.9 \%(\mathrm{w} / \mathrm{v}) \mathrm{NaCl}$ ). After $15 \mathrm{~min}$ of incubation the fluorescence was recorded at an excitation wavelength of $488 \mathrm{~nm}$ by use of an argon laser in combination with an emission long pass filter LP $505 \mathrm{~nm}$. Images were obtained with a Zeiss LD Achroplan 40x/0.60 NA objective. Digital image acquisition and analysis of the CLSM optical thin sections were performed with the Zeiss LSM software (version 3.2). For better visibility the fluorescence signals were stained with two different colors for imaging.

\section{Purification of extracellular lipase from $P$. aeruginosa}

Lipase protein was purified by a two-step chromatographic procedure as described earlier [38]. In brief: lipase protein was produced in larger amounts by growing $P$. aeruginosa PABST7.1/pUCPL6A in $10 \mathrm{ml}$ of double strength Luria Broth $(2 \times \mathrm{LB})$ containing $200 \mu \mathrm{g} / \mathrm{ml}$ carbenicillin and $50 \mu \mathrm{g} / \mathrm{ml}$ tetracycline in a $100 \mathrm{ml}$ Erlenmeyer flask after inoculation with a single colony. Cells were grown overnight at $30^{\circ} \mathrm{C}$, lipase gene expression was induced by addition of $0.4 \mathrm{mM}$ IPTG and cells were further grown for $24 \mathrm{~h}$.

Lipase expression cultures of recombinant $P$. aeruginosa were centrifuged; the culture supernatant was sterile filtered and concentrated by ultrafiltration by a factor of 15. One $\mathrm{ml}$ of the concentrated culture supernatant was mixed with $1 \mathrm{ml} 10 \mathrm{mM}$ Tris- $\mathrm{HCl}$ (pH 8.0), $100 \mathrm{mM}$ $\mathrm{NaCl}$ and loaded onto a Fractogel EMD Bio SECchromatography column (length: $500 \mathrm{~mm}$, inner diameter: $15 \mathrm{~mm}$; Merck, Darmstadt, Germany) at room temperature. Proteins were eluted at $1 \mathrm{ml} / \mathrm{min}$ using the same 
buffer. Fractions containing the highest lipase activity (usually 15-20 fractions) were pooled and loaded onto an Uno-Q1 column (Bio-Rad, Munich, Germany), preequilibrated with buffer A (20 mM Tris- $\mathrm{HCl}$ pH 8.0, $100 \mathrm{mM} \mathrm{NaCl}$ ) and connected to an FPLC unit (Pharmacia, Sweden). Proteins were eluted at $0.5 \mathrm{ml} / \mathrm{min}$ with the following $\mathrm{NaCl}$ gradient: 0-7 min with buffer $\mathrm{A}, 8-17 \mathrm{~min}$ from $100 \mathrm{mM}$ to $400 \mathrm{mM} \mathrm{NaCl}$ in buffer $\mathrm{A}, 18-27 \mathrm{~min}$ from $400 \mathrm{mM}$ to $1 \mathrm{M} \mathrm{NaCl}$ in buffer $\mathrm{A}, 28-32 \min 1 \mathrm{M}$ $\mathrm{NaCl}, 33-37 \mathrm{~min}$ from $1 \mathrm{M}$ to $2 \mathrm{M} \mathrm{NaCl}$ in buffer $\mathrm{A}$.

\section{Purification of bacterial alginate and other polysaccharides}

Bacterial alginate was isolated and purified from biofilm cultures of $P$. aeruginosa SG81 (PIA, $36^{\circ} \mathrm{C}, 24 \mathrm{~h}$ ) as described before [68]. Additionally, the bacterial polysaccharides dextran from Leuconostoc mesenteroides (SigmaAldrich, Munich, Germany), xanthan from Xanthomonas campestris (Sigma-Aldrich, Munich, Germany), levan from Erwinia herbicola (Fluka, Munich, Germany) and alginate (sodium salt) produced by brown algae (Manucol LHF, Nutra Sweet Kelco Company, Chicago, USA) were used. For further purification of dextran and algal alginate, $2 \mathrm{~g}$ of the polysaccharides were dissolved in $100 \mathrm{ml}$ deionized water. After centrifugation of the solutions at $40,000 \times \mathrm{g}$ for $30 \mathrm{~min}$ the supernatants were collected, again centrifuged at 40,000 $\times \mathrm{g}$ for $30 \mathrm{~min}$ and dialyzed (exclusion size: $12-14 \mathrm{kDa}$ ) twice against 51 deionized water overnight. Finally, the polysaccharides were recovered by lyophilization. For further purification of xanthan and levan, the polysaccharides were dissolved in a concentration of $2.5 \mathrm{mg} / \mathrm{ml}$ in $50 \mathrm{mM}$ Tris $-\mathrm{HCl}$ buffer ( $\mathrm{pH} 7.5$ ) containing $2 \mathrm{mM} \mathrm{MgCl}_{2}$. After addition of Benzonase (Merck, Darmstadt, Germany; final concentration $5 \mathrm{U} / \mathrm{ml}$ ) and incubation for $4 \mathrm{~h}$ at $36^{\circ} \mathrm{C}$, proteinase K (Sigma-Aldrich, Munich, Germany) was added (final concentration $5 \mu \mathrm{g} / \mathrm{ml}$ ) followed by incubation at $36^{\circ} \mathrm{C}$ for $24 \mathrm{~h}$. After centrifugation at $20,000 \times \mathrm{g}$ for $30 \mathrm{~min}$, the supernatants were dialyzed (exclusion size: $12-14 \mathrm{kDa}$ ) twice against 51 deionized water overnight and finally lyophilized.

\section{Chemical deacetylation of bacterial alginate}

Deacetylation of bacterial alginates was performed as described before [20]. For complete deacetylation $25 \mathrm{mg}$ purified alginate from $P$. aeruginosa SG81 was dissolved in $5 \mathrm{ml}$ deionized water. After addition of $2.5 \mathrm{ml} 0.3 \mathrm{M}$ $\mathrm{NaOH}$ and incubation for $1 \mathrm{~h}$ at room temperature the $\mathrm{pH}$ was adjusted to 8.0 with $0.5 \mathrm{M} \mathrm{HCl}$. Finally, the solution was dialyzed (exclusion size: $12-14 \mathrm{kDa}$ ) twice against 51 deionized water overnight and lyophilized.

\section{Quantification of lipase activity}

Lipase activity was measured with para-nitrophenyl palmitate (pNPP) as a substrate as described before [45].
An absorbance at $410 \mathrm{~nm}$ of 1.0 per 15 min corresponds to a lipase activity of $48.3 \mathrm{nmol} / \mathrm{min} \mathrm{x} \mathrm{ml}$ solution.

\section{Quantification of polysaccharides}

Total carbohydrate and uronic acid (alginate) concentrations were determined with the phenol-sulfuric acid method [70] and the hydroxydiphenyl assay [71], respectively, using purified alginate from $P$. aeruginosa SG81 as a standard.

\section{Interaction of lipase with polysaccharides}

For the investigation of interactions between lipase and polysaccharides a microtiter plate (polystyrene, Nalgene Nunc, Roskilde, Denmark) binding assay was applied. Purified polysaccharides were dissolved in $0.9 \%(\mathrm{w} / \mathrm{v})$ $\mathrm{NaCl}$ solution and incubated for $15 \mathrm{~min}$ at $90^{\circ} \mathrm{C}$ to inactivate possibly remained enzymes. After cooling on ice, $100 \mu \mathrm{l}$ of these polysaccharides in various concentrations $(0-5 \mathrm{mg} / \mathrm{ml})$ were immobilized by drying in the wells of microtiter plates at $30^{\circ} \mathrm{C}$ overnight, followed by a washing step with $200 \mu \mathrm{l}$ distilled water (A. dest.) to remove $\mathrm{NaCl}$. Afterwards $20 \mu \mathrm{l}$ of purified lipase LipA from $P$. aeruginosa PABST7.1/pUCPL6A (72 ng/ml A. dest.) was added and incubated at $30^{\circ} \mathrm{C}$ for $30 \mathrm{~min}$. Non-bound lipase was removed by two washing steps with $100 \mu \mathrm{l}$ A. dest. each. Bounded lipase was detected via activity measurement in the microtiter plate using pNPP as substrate. The cleavage of the substrate was monitored at $405 \mathrm{~nm}$ in a microtiter plate reader. All experiments were performed in duplicates and repeated three times.

\section{Heat treatment of lipase}

The stabilization of lipases through the interaction with alginate was investigated by heat treatment of purified lipase in presence and absence of polysaccharides. One volume purified lipase LipA from $P$. aeruginosa PABST7.1/ pUCPL6A (36 $\mu \mathrm{g} / \mathrm{ml} \mathrm{A}$. dest.) was mixed with one volume purified polysaccharides $(2 \mathrm{mg} / \mathrm{ml}$ in $100 \mathrm{mM}$ Tris $-\mathrm{HCl}$ buffer, $\mathrm{pH}$ 7.5), which were previously heated (15 min, $90^{\circ} \mathrm{C}$ ) and afterwards cooled on ice to room temperature. After pre-incubation for $30 \mathrm{~min}$ at room temperature the samples were incubated for $0-60 \mathrm{~min}$ at $70^{\circ} \mathrm{C}$ to determine lipase inactivation kinetics. Moreover, the samples were incubated for $20 \mathrm{~min}$ at different temperatures $\left(37^{\circ} \mathrm{C} ; 50^{\circ} \mathrm{C} ; 60^{\circ} \mathrm{C} ; 70^{\circ} \mathrm{C} ; 80^{\circ} \mathrm{C} ; 90^{\circ} \mathrm{C}\right)$ to determine $\mathrm{T}_{50} . \mathrm{T}_{50}$ represents the temperature at which incubation for $20 \mathrm{mi}$ nutes reduces the enzymes activity by half. Every $10 \mathrm{~min}$ the residual lipase activities were detected after cooling on ice, using pNPP as substrate. All experiments were performed in duplicates and repeated three times.

\section{Degradation of lipase by proteases}

The protection of lipase from proteolytic degradation through the interaction with alginate was studied by 
using purified elastase LasB from $P$. aeruginosa (EMD4Biosciences, San Diego, USA). Briefly, $0.5 \mathrm{ml}$ purified lipase LipA from $P$. aeruginosa PABST7.1/ pUCPL6A $(36 \mu \mathrm{g} / \mathrm{ml} \mathrm{A}$. dest.) was mixed with $0.5 \mathrm{ml}$ purified polysaccharides $(2 \mathrm{mg} / \mathrm{ml}$ in $100 \mathrm{mM}$ Tris$\mathrm{HCl}$ buffer, $\mathrm{pH} \mathrm{7.5)}$ previously heated for $15 \mathrm{~min}$ and $90^{\circ} \mathrm{C}$ and afterwards cooled on ice to room temperature. After pre-incubation for $30 \mathrm{~min}$ at room temperature, $20 \mu \mathrm{l}$ purified elastase $(0.1 \mathrm{mg} / \mathrm{ml}$ with $25 \mathrm{U} / \mathrm{ml}$ in A. dest.) were added. After $24 \mathrm{~h}$ incubation at $37^{\circ} \mathrm{C}$ the residual lipase activity was detected, using $\mathrm{pNPP}$ as a substrate. All experiments were performed in duplicates and repeated three times.

\section{Modeling of lipase-alginate interaction}

The protein structure was based on the crystal structure of the lipase protein resulting from the X-ray diffraction analysis of a lipase protein [37]. The crystal structure was obtained from the RCSB protein data bank [72]. The hydrogens of the amino acids were adjusted according to the $\mathrm{pKs}$ values of the amino acids at a $\mathrm{pH}$ value of 7.0. Therefore, the resulting net charge of the protein was in accordance to an aqueous solution of $\mathrm{pH}=7.0$. Inter- and intramolecular interactions were calculated by a molecular mechanics force field approach. The here used atom types and atomic partial charges of the CHARMM27 force field were described before [73].

In order to calculate the lipase - alginate interaction a modified docking procedure was applied including a water shell around the protein and alginate chain. In this procedure the lipase and alginate atoms were randomly moved. This resulted in a slight rotation and translation of the molecules. In consequence the potential energy of the resulting structure was minimized and saved. The step of changing the atomic positions was repeated several thousand times and the potential energy differences between all collected structures were checked. The structures with the lowest potential energies were extracted.

\section{Statistical analyses}

The significance of the data were analysed using the two-sample t-test and one way analyses of variance (ANOVA; [74]). A significant difference was considered to be $p<0.05$.

\section{Competing interests}

The authors declare that they have no competing interests.

\section{Authors' contributions}

PT performed the experiments, HK performed molecular modeling, JW conceived the study; PT, FR and JW wrote the manuscript. KEJ and HCF coordinate the work. All authors read and approved the final manuscript.

\section{Acknowledgements}

Financial support from the "Deutsche Forschungsgemeinschaft" (DFG grant WI 831/3-1) is gratefully acknowledged.

\section{Author details}

'Department of Aquatic Microbiology, University of Duisburg-Essen, Faculty of Chemistry, Biofilm Centre, Universitätsstrasse 5, D-45141, Essen, Germany. ${ }^{2}$ University of Duisburg-Essen, CAM-D Technologies GmbH, Schützenbahn 70, D-45117, Essen, Germany. ${ }^{3}$ Institute for Molecular Enzyme Technology, Heinrich-Heine-University of Duesseldorf, Research Centre Juelich, Stetternicher Forst, D-52425, Juelich, Germany. ${ }^{4}$ Current adress: Institute for Microbiology, Technische Universität Braunschweig, Spielmannstrasse 7, D-38106, Braunschweig, Germany. ${ }^{5}$ Current adress: Institute for Pharmaceutical Biotechnology/ Ulm Centre for Peptide Pharmaceuticals, University Ulm, Albert-Einstein-Allee 11, D-89081, Ulm, Germany.

Received: 19 March 2013 Accepted: 8 July 2013

Published: 13 July 2013

\section{References}

1. Tielen P, Rosenau F, Wilhelm S, Jaeger KE, Flemming HC, Wingender J: Extracellular enzymes affect biofilm formation of mucoid Pseudomonas aeruginosa. Microbiology 2010, 156(Pt 7):2239-2252.

2. Van Delden C: Virulence factors in Pseudomonas aeruginosa. In Pseudomonas. Edited by Ramos JL. New York: Kluwer Academics/Plenum Publisher; 2004:3-46.

3. Pier GB: Pseudomonas aeruginosa: a key problem in cystic fibrosis. ASM News 1998, 64:339-347.

4. Costerton JW, Stewart PS, Greenberg EP: Bacterial biofilms: a common cause of persistent infections. Science 1999, 284(5418):1318-1322.

5. Worlitzsch D, Tarran R, Ulrich M, Schwab U, Cekici A, Meyer KC, Birrer P Bellon G, Berger J, Weiss T, et al: Effects of reduced mucus oxygen concentration in airway Pseudomonas infections of cystic fibrosis patients. J Clin Invest 2002, 109(3):317-325.

6. Son MS, Matthews WJ Jr, Kang Y, Nguyen DT, Hoang TT: In vivo evidence of Pseudomonas aeruginosa nutrient acquisition and pathogenesis in the lungs of cystic fibrosis patients. Infect Immun 2007, 75(11):5313-5324.

7. Granstrom M, Ericsson A, Strandvik B, Wretlind B, Pavlovskis OR, Berka R, Vasil ML: Relation between antibody response to Pseudomonas aeruginosa exoproteins and colonization/infection in patients with cystic fibrosis. Acta Paediatr Scand 1984, 73(6):772-777.

8. Döring G, Goldstein W, Roll A, Schiotz PO, Hoiby N, Botzenhart K: Role of Pseudomonas aeruginosa exoenzymes in lung infections of patients with cystic fibrosis. Infect Immun 1985, 49(3):557-562.

9. Wingender J, Flemming HC: The biofilm matrix. Nature Rev Microbiol 2010, 8:623-633.

10. Cryz SJ, Iglewski BH: Production of alkaline protease by Pseudomonas aeruginosa. J Clin Microbiol 1980, 12(1):131-133.

11. Bever RA, Iglewski BH: Molecular characterization and nucleotide sequence of the Pseudomonas aeruginosa elastase structural gene. J Bacterio/ 1988, 170(9):4309-4314.

12. Ostroff RM, Vasil ML: Identification of a new phospholipase $\mathrm{C}$ activity by analysis of an insertional mutation in the hemolytic phospholipase $\mathrm{C}$ structural gene of Pseudomonas aeruginosa. J Bacteriol 1987, 169(10):4597-4601.

13. Stuer W, Jaeger KE, Winkler UK: Purification of extracellular lipase from Pseudomonas aeruginosa. J Bacteriol 1986, 168(3):1070-1074.

14. Martinez A, Ostrovsky P, Nunn DN: LipC, a second lipase of Pseudomonas aeruginosa, is $\mathrm{LipB}$ and $\mathrm{Xcp}$ dependent and is transcriptionally regulated by pilus biogenesis components. Mol Microbiol 1999, 34(2):317-326.

15. Galloway DR: Pseudomonas aeruginosa elastase and elastolysis revisited: recent developments. Mol Microbiol 1991, 5(10):2315-2321.

16. König B, Jaeger KE, Sage AE, Vasil ML, König W: Role of Pseudomonas aeruginosa lipase in inflammatory mediator release from human inflammatory effector cells (platelets, granulocytes, and monocytes. Infect Immun 1996, 64(8):3252-3258.

17. Pier GB: Cystic fibrosis and Pseudomonas infections. Lancet 1983, 2(8353):794.

18. Sherbrock-Cox V, Russell NJ, Gacesa P: The purification and chemical characterisation of the alginate present in extracellular material produced by mucoid strains of Pseudomonas aeruginosa. Carbohydr Res 1984, 135(1):147-154.

19. Govan JR: Characteristics of mucoid Pseudomonas aeruginosa in vitro and in vivo. In Pseudomonas infection and alginates - Biochemistry, genetics and pathology. Edited by Gacesa P, Russell NJ. London/New York/Tokyo: Chapman and Hall; 1990:50-75. 
20. Evans $L R$, Linker $A$ : Production and characterization of the slime polysaccharide of Pseudomonas aeruginosa. J Bacteriol 1973, 116(2):915-924.

21. Chitnis CE, Ohman DE: Cloning of Pseudomonas aeruginosa algG, which controls alginate structure. J Bacterio/ 1990, 172(6):2894-2900.

22. Skjar-Braek G, Grasgalen H, Larsen B: Monomer sequence and acetylation pattern in some bacterial alginates. Carbohydr Res 1986, 154:239-250.

23. Lee JW, Ashby RD, Day DF: Role of acetylation on metal induced precipitation of alginates. Carbohydr Polym 1996, 29:337-345.

24. Tielen P, Strathmann M, Jaeger KE, Flemming HC, Wingender J: Alginate acetylation influences initial surface colonization by mucoid Pseudomonas aeruginosa. Microbiol Res 2005, 160(2):165-176.

25. Lattner D, Flemming HC, Mayer C: 13C-NMR study of the interaction of bacterial alginate with bivalent cations. Int J Biol Macromol 2003, 33(1-3):81-88.

26. Skjar-Braek G, Zanetti FSP: Effect of acetylation on some solution and gelling properties of alginates. Carbohydr Res 1989, 185:131-138.

27. Donlan RM, Costerton JW: Biofilms: survival mechanisms of clinically relevant microorganisms. Clin Microbiol Rev 2002, 15(2):167-193.

28. Körstgens $V$, Flemming HC, Wingender J, Borchard W: Uniaxial compression measurement device for investigation of the mechanical stability of biofilms. J Microbiol Methods 2001, 46(1):9-17.

29. Allison DG, Matthews MJ: Effect of polysaccharide interactions on antibiotic susceptibility of Pseudomonas aeruginosa. J App/ Bacteriol 1992 73(6):484-488

30. Grobe S, Wingender J, Flemming HC: Capability of mucoid Pseudomonas aeruginosa to survive in chlorinated water. Int J Hyg Environ Health 2001, 204(2-3):139-142.

31. Pier GB, Coleman F, Grout M, Franklin M, Ohman DE: Role of alginate O acetylation in resistance of mucoid Pseudomonas aeruginosa to opsonic phagocytosis. Infect Immun 2001, 69(3):1895-1901.

32. Leid JG, Willson CJ, Shirtliff ME, Hassett DJ, Parsek MR, Jeffers AK: The exopolysaccharide alginate protects Pseudomonas aeruginosa biofilm bacteria from IFN-gamma-mediated macrophage killing. J Immuno/ 2005, 175(11):7512-7518.

33. Wingender J, Winkler U: A novel biological function of algiante in Pseudomonas aeruginosa and its mucoid mutants: stimulation of exolipase. FEMS Microbiol Lett 1984, 21:63-69.

34. Wingender J, Volz S, Winkler UK: Interaction of extracellular Pseudomonas lipase with alginate and its potential use in biotechnology. Appl Microbiol Biotechnol 1987, 27:139-145.

35. Sharma S, Gupta MN: Alginate as a macroaffinity ligand and an additive for enhanced activity and thermostability of lipases. Biotechnol Appl Biochem 2001, 33(Pt 3):161-165.

36. Arpigny JL, Jaeger KE: Bacterial lipolytic enzymes: classification and properties. Biochem J 1999, 343(Pt 1):177-183.

37. Nardini M, Lang DA, Liebeton K, Jaeger KE, Dijkstra BW: Crystal structure of Pseudomonas aeruginosa lipase in the open conformation. The prototype for family I.1 of bacterial lipases. J Biol Chem 2000, 275(40):31219-31225.

38. Liebeton K, Zonta A, Schimossek K, Nardini M, Lang D, Dijkstra BW, Reetz MT, Jaeger KE: Directed evolution of an enantioselective lipase. Chem Biol 2000, 7(9):709-718

39. Rosenau F, Jaeger K: Bacterial lipases from Pseudomonas: regulation of gene expression and mechanisms of secretion. Biochimie 2000, 82(11):1023-1032

40. Wingender J, Jaeger KE, Flemming HC: Interaction between extracellular polysaccharides and enzymes. In Microbial extracellular polymeric substances. Edited by Wingender J, Neu T, Flemming HC. Berlin/Heidelberg/ New York: Springer Verlag; 1999:231-247.

41. Wingender J: Interactions of alginate with exoenzymes. In Pseudomonas infection and alginates - Biochemistry, genetics and pathology. Edited by Gacesa P, Russell NJ. London/New York/Tokyo: Chapman and Hall; 1990:160-180

42. Borriello G, Richards L, Ehrlich GD, Stewart PS: Arginine or nitrate enhances antibiotic susceptibility of Pseudomonas aeruginosa in biofilms. Antimicrob Agents Chemother 2006, 50(1):382-384.

43. Auerbach ID, Sorensen C, Hansma HG, Holden PA: Physical morphology and surface properties of unsaturated Pseudomonas putida biofilms. J Bacteriol 2000, 182(13):3809-3815.
44. Steinberger RE, Allen AR, Hansa HG, Holden PA: Elongation correlates with nutrient deprivation in Pseudomonas aeruginosa-unsaturates biofilms. Microb Ecol 2002, 43(4):416-423.

45. Winkler UK, Stuckmann M: Glycogen, hyaluronate, and some other polysaccharides greatly enhance the formation of exolipase by Serratia marcescens. J Bacteriol 1979, 138(3):663-670.

46. Körstgens V, Flemming HC, Wingender J, Borchard W: Influence of calcium ions on the mechanical properties of a model biofilm of mucoid Pseudomonas aeruginosa. Water Sci Technol 2001, 43(6):49-57.

47. Rosenau F, Isenhardt S, Gdynia A, Tielker D, Schmidt E, Tielen P, Schobert M, Jahn D, Wilhelm S, Jaeger KE: Lipase LipC affects motility, biofilm formation and rhamnolipid production in Pseudomonas aeruginosa. FEMS Microbiol Lett 2010, 309(1):25-34.

48. Strathmann M, Wingender J, Flemming HC: Application of fluorescently labelled lectins for the visualization and biochemical characterization of polysaccharides in biofilms of Pseudomonas aeruginosa. J Microbiol Methods 2002, 50(3):237-248.

49. Schürks N, Wingender J, Flemming HC, Mayer C: Monomer composition and sequence of alginates from Pseudomonas aeruginosa. Int J Biol Macromol 2002, 30(2):105-111.

50. Sikorski P, Mo F, Skjak-Braek G, Stokke BT: Evidence for eggbox-compatible interactions in calcium-alginate gels from fiber X-ray diffraction. Biomacromolecules 2007, 8(7):2098-2103.

51. Kemmling A, Kämper M, Flies C, Schieweck O, Hoppert M: Biofilms and extracellular matrices on geomaterils. Environ Geol 2004, 46:429-435.

52. Leza A, Plameros B, Garcia JO, Galindo E, Sobéron-Chávez G: Xanthomonas campstris as a host for the production of recombinant Pseudomonas aeruginosa lipase. J Ind Microbiol 1996, 16:22-28.

53. Duckworth M, Turvey JR: An extracellular agarase from a Cytophaga species. Biochem J 1969, 113:139-142

54. Kuwabara S, Lloyd PH: Protein and carbohydrate moieties of a preparation of B-lactamase II. Biochem J 1971, 124:215-220.

55. Nouwens AS, Beatson SA, Whitchurch CB, Walsh BJ, Schweizer HP, Mattick JS, Cordwell SJ: Proteome analysis of extracellular proteins regulated by the las and rhl quorum sensing systems in Pseudomonas aeruginosa PAO1. Microbiology 2003, 149(Pt 5):1311-1322.

56. Folders J, Tommassen J, Van Loon LC, Bitter W: Identification of a chitinbinding protein secreted by Pseudomonas aeruginosa. J Bacterio/ 2000, 182(5):1257-1263.

57. $\mathrm{Vu} \mathrm{TH}$, Werb Z: Matrix metalloproteinases: effectors of development and normal physiology. Genes Dev 2000, 14(17):2123-2133.

58. Kearns DB, Bonner PJ, Smith DR, Shimkets LJ: An extracellular matrixassociated zinc metalloprotease is required for dilauroyl phosphatidylethanolamine chemotactic excitation in Myxococcus xanthus. J Bacteriol 2002, 184(6):1678-1684.

59. Imeson AP, Ledward DA, Mitchell JR: On the nature of the interaction between some anionic polysaccharides and proteins. Sci Food Agric 1977, 28:661-668.

60. Ying QL, Kemme M, Simon SR: Alginate, the slime exopolysaccharide of Pseudomonas aeruginosa, binds human leukocyte elastase, retards inhibition by alpha 1-proteinase inhibitor, and accelerates inhibition by secretory leukoprotease inhibitor. Am J Respir Cell Mol Biol 1996, 15(2):283-291.

61. Franklin MJ, Ohman DE: Identification of algF in the alginate biosynthetic gene cluster of Pseudomonas aeruginosa which is required for alginate acetylation. J Bacteriol 1993, 175(16):5057-5065.

62. Franklin MJ, Ohman DE: Identification of algl and algJ in the Pseudomonas aeruginosa alginate biosynthetic gene cluster which are required for alginate O acetylation. J Bacteriol 1996, 178(8):2186-2195.

63. Wilhelm S, Rosenau F, Becker S, Buest S, Hausmann S, Kolmar H, Jaeger KE: Functional cell-surface display of a lipase-specific chaperone. Chem Bio Chem 2007, 8(1):55-60.

64. Kovach ME, Phillips RW, Elzer PH, Roop RM 2nd, Peterson KM: pBBR1MCS: a broad-host-range cloning vector. Biotechniques 1994, 16(5):800-802.

65. Simon R, Priefer U, Pühler A: A broad host range mobilization system for in vitro genetic engeneering: transposon mutagenesis in Gram-negative bacteria. Biological Technology 1983, 1:784-791.

66. Ohman DE, Chakrabarty AM: Genetic mapping of chromosomal determinants for the production of the exopolysaccharide alginate in a Pseudomonas aeruginosa cystic fibrosis isolate. Infect Immun 1981, 33(1):142-148. 
67. Grobe S, Wingender J, Truper HG: Characterization of mucoid Pseudomonas aeruginosa strains isolated from technical water systems. J Appl Bacteriol 1995, 79(1):94-102.

68. Wingender J, Strathmann M, Rode A, Leis A, Flemming HC: Isolation and biochemical characterization of extracellular polymeric substances from Pseudomonas aeruginosa. Methods Enzymol 2001, 336:302-314.

69. Singer VL, Paragas VB, Larison KD, Wells KS, Fox CJ, Haugland RP. Fluorescence-based signal amplification technology. Am Biotechnol Lab 1994, 12(11):55-56. 58.

70. Dubois M, Gilles K, Hamilton JK, Rebers PA, Smith F: A colorimetric method for the determination of sugars. Nature 1951, 168(4265):167.

71. Blumenkrantz N, Asboe-Hansen G: New method for quantitative determination of uronic acids. Anal Biochem 1973, 54(2):484-489.

72. Berman HM, Westbrook J, Feng Z, Gilliland G, Bhat TN, Weissig H, Shindyalov IN, Bourne PE: The protein data bank. Nucleic Acids Res 2000 28(1):235-242

73. Mackerell JAD, Bashford D, Bellott M, Dunbrack JRL, Evanseck JD, Field MJ, Fischer S, Gao J, Guo H, Ha S, et al: All-atomempirical potential for molecular modeling and dynamics studies of proteins. J Phys Chem 1998, 102:3586-3616.

74. Fagerland MW, Sandvik L: Performance of five two-sample location tests for skewed distributions with unequal variances. Contemp Clin Trials 2009, 30(5):490-496

doi:10.1186/1471-2180-13-159

Cite this article as: Tielen et al:: Interaction between extracellular lipase LipA and the polysaccharide alginate of Pseudomonas aeruginosa. BMC Microbiology 2013 13:159.

\section{Submit your next manuscript to BioMed Central and take full advantage of:}

- Convenient online submission

- Thorough peer review

- No space constraints or color figure charges

- Immediate publication on acceptance

- Inclusion in PubMed, CAS, Scopus and Google Scholar

- Research which is freely available for redistribution 